\title{
Effectiveness of therapeutic groups in psychosocial care: analysis in the light of yalom's therapeutic factors
}

\author{
Efetividade dos grupos terapêuticos na atenção psicossocial: análise à luz do referencial dos fatores terapêuticos
}

Eficacia de los grupos terapéuticos en la atención psicosocial: análisis a la luz del referencial de factores terapéuticos

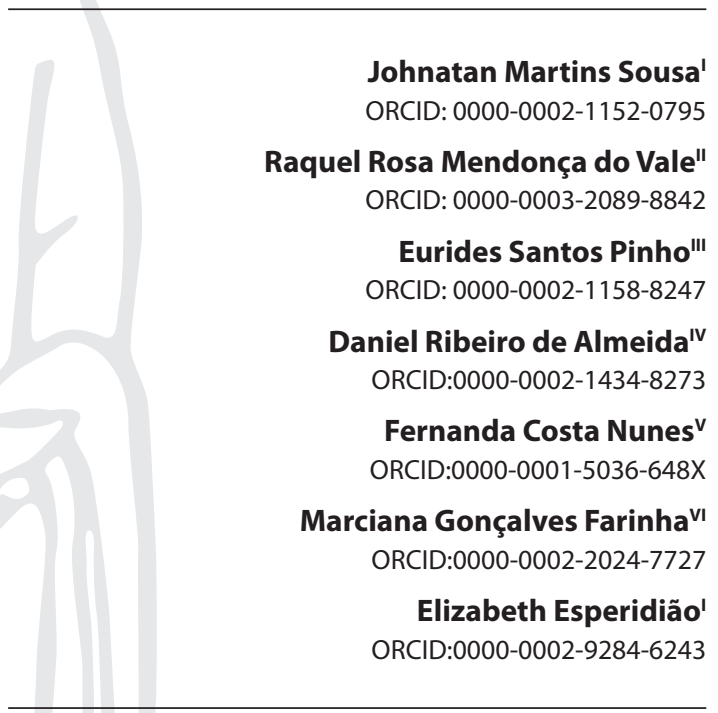

'Universidade Federal de Goiás. Goiânia, Goiás, Brazil. "Centro Universitário de Mineiros. Trindade, Goiás, Brazil. I"Secretaria Municipal de Saúde de Aparecida de Goiânia. Aparecida de Goiânia, Goiás, Brazil

"Vontifícia Universidade Católica de Goiás. Goiânia Goiás, Brazil.

` Secretaria da Saúde do Estado de Goiás. Goiânia, Goiás, Brazil.

"Universidade Federal de Uberlândia. Uberlândia, Minas Gerais, Brazil.

How to cite this article: Sousa JM, Vale RRM, Pinho ES, Almeida DR, Nunes FC, Farinha MG, et al. Effectiveness of therapeutic groups in psychosocial care: analysis in the light of yalom's therapeutic factors. Rev Bras Enferm. 2020;73(Suppl 1):e20200410. doi: http://dx.doi.org/10.1590/0034-7167-2020-0410

\section{Corresponding author: Johnatan Martins Sousa E-mail: johnatanfen.ufg@gmail.com}

\section{ABSTRACT}

Objective: to describe professionals' perceptions about the therapeutic effectiveness of group care. Method: a descriptive, exploratory, qualitative research of the type of intervention carried out with 30 professionals from Psychosocial Care Centers for Alcohol and Drugs in a municipality in center-westerns Brazil, from March to April 2019. Self-applicable instruments and round circles were used. The emerging data were submitted to content analysis. Results: professionals perceive the benefits of group practices and relate them to some therapeutic factors in the group. It is evident the little formal and systematized knowledge about the group process elements. Final considerations: the therapeutic effectiveness of group processes is compromised due to absence of systematic records that allow to perceive the therapeutic progress of users, even though professionals perceive the emergence of therapeutic factors of the groups in the context of psychosocial care.

Descriptors: Group Processes; Effectiveness; Mental Health; Community Mental Health Services; Health Personnel.

\section{RESUMO}

Objetivo: descrever a percepção dos profissionais sobre a efetividade terapêutica dos atendimentos grupais. Método: pesquisa descritiva, exploratória, qualitativa, do tipo intervenção, realizada com 30 profissionais de Centros de Atenção Psicossocial Álcool e Drogas de um município do Centro-Oeste brasileiro, de março a abril de 2019. Utilizaram-se instrumentos autoaplicáveis e rodas de conversa. Os dados emergentes foram submetidos à análise de conteúdo. Resultados: os profissionais percebem os benefícios das práticas grupais e os relacionam a alguns fatores terapêuticos do grupo. Fica evidente o pouco conhecimento formal e sistematizado sobre os elementos do processo grupal. Considerações finais: o indício da efetividade terapêutica dos processos grupais está comprometido devido à ausência de registros sistematizados que permitam perceber a evolução terapêutica dos usuários, ainda que os profissionais percebam a emersão dos fatores terapêuticos dos grupos no contexto da atenção psicossocial.

Descritores: Processos Grupais; Efetividade; Saúde Mental; Serviços Comunitários de Saúde Mental; Pessoal de Saúde.

\section{RESUMEN}

Objetivo: describir la percepción de lo sprofesionales sobre la efectividad terapéutica del cuidado grupal. Método: investigación descriptiva, exploratoria, cualitativa, tipo intervención, realizada con 30 profesionales de los Centros de Atención Psicosocial por Alcohol y Drogas de un municipio del Medio Oeste brasileño, de marzo a abril de 2019. Se utilizaron instrumentos autoaplicables y círculos de conversación. Los datos emergentes se sometieron a análisis de contenido. Resultados: los profesionales perciben los beneficios de las prácticas grupales y los relacionan con algunos factores terapéuticos en el grupo. Es evidente el escaso conocimiento formal y sistematizado sobre los elementos del proceso grupal. Consideraciones finales: la indicación de la efectividad terapéutica de los procesos grupales se ve comprometida por la ausencia de registros sistemáticos que permitan percibir la evolución terapéutica de los usuarios, auncuando los profesionales perciban la emergencia de los factores terapéuticos de los grupos en el contexto de la atención psicossocial.

Descriptores: Procesos de Grupo; Efectividad; Salud Mental; Servicios Comunitarios de Salud Mental; Personal de Salud.
EDITOR IN CHIEF: Antonio José de Almeida Filho ASSOCIATE EDITOR: Andrea Bernardes 


\section{INTRODUCTION}

In Psychosocial Care Centers (CAPS - Centros de Atenção Psicossocial), most therapeutic offerings are developed in groups. It is known that group activities enable creating means of welcoming and allows sharing experiences, functioning as an important potential for building meanings in the face of emptiness and impoverishment caused by exclusion and subjection ${ }^{(1,2)}$. Living the group process allows numerous therapeutic results, mainly in the reality of specialized mental health services.

Irving D. Yalom, an American psychiatrist, has contributed immensely to the study of groups through the systematization of 11 therapeutic factors (TFs) that are fundamental to understand the process of change that occurs due to human interaction in the group. This knowledge allows coordinators to select the necessary strategies to maximize the group's power in different scenarios. The TFs that form the basis of an effective approach to practice with groups are instillation of hope, universality, information sharing, altruism, corrective recap of the primary family group, development of socialization techniques, imitative behavior, interpersonal learning, group cohesion, catharsis and existential factors ${ }^{(3)}$.

The group is able to provide similar benefits to individual therapy, through the manifestation of several TFs that contribute to attitudinal changes arising from articulation of facilitator's performance, the actions of group members and subjects themselves. Moreover, these factors represent a relevant parameter for assessing and (re) planningthe group process, as their presence reveals that the group's conduct is on the right path, while its absence signals the need for improvement of the group approach by the coordinator ${ }^{(3-5)}$.

The relevance of group practices in mental health has been discussed in recent studies as important tools for psychosocial assistance for individuals in need of mental care ${ }^{(6)}$. Group interaction fosters hope and optimism, allowing participants to realize that they are not the only ones experiencing certain problems. Exchange of information, freedom to express repressed or blocked emotions, as well as developing the ability to relate also produce intense well-being for those who participate in this type of care ${ }^{(7)}$.

A study with professionals working in mental health services found that the deficiency of theoretical constructs in relation to the group process can limit developing group therapeutic activities. From the moment that a worker does not master the task of coordination, the group tends to decrease its therapeutic potential, and often it becomes just a group of people ${ }^{(8)}$.

TFs such as group cohesion are important for group maintenance and for other TF production. The group coordinator can lead the group to cohesion, when he or she manages to associate his or her competence with formation of a good therapeutic alliance. However, conclusive data are lacking that group cohesion, therapeutic alliance and the facilitator's competence predict the outcome of treatment ${ }^{(9)}$.

Professionals who coordinate groups must have knowledge of group dynamics and process and of the other elements that permeate the practice with groups as a welcoming and caring space. Based on this perception, professionals will be able to plan group meetings in order to optimize the group's conduct to encourage coexistence of these elements.

Thus, as group care is a relevant care strategy in the field of mental health ${ }^{(10-11)}$, it is important to discuss and discuss the issue of group therapeutics, to investigate how these practices are being implemented in Brazil in this specific scenario(12), taking into account the relevance of the group's TF in health promotion and rehabilitation processes ${ }^{(13)}$.

There is evidence that TFs become excellent tools for help when the group is properly conducted, as they are tools that assess group intervention effectiveness ${ }^{(14)}$. Studies in this field can support TF identification in group practices, in addition to contributing to the improvement of the group approach and the achievement of the desired results by professionals in specialized mental health services.

\section{OBJECTIVE}

This study aims todescribe professionals' perceptions about the therapeutic effectiveness of group care.

\section{METHODS}

\section{Ethical aspects}

The entire development of the research followed the ethical precepts present in Resolution 466/2012 ${ }^{(15)}$ of the Brazilian National Health Council (Conselho Nacional de Saúde), being approved by the Research Ethics Committee with Human Beings at UFG. To ensure professionals' and participating services' anonymity, they were coded by the letter P and numbers (P1 to P29 and CAPS 1 to CAPS 4, respectively). All employees agreed to participate in the study by signing the Informed Consent Form (ICF).

\section{Type of study and theoretical-methodological framework}

This descriptive-exploratory research was developed along the lines of intervention research, based on the qualitative approach principles. Interaction between researcher/investigated object/participants, as recommended by this type of study, was relevant in the collective construction of the elements that make up the research. Such interaction combined intervention and investigative process aiming at a new relationship between the formation of knowledge, theory/practice, subject/object, in order to provide analysis and the various forms of manifestation of the phenomenon in question ${ }^{(16-20)}$.

It is also worth mentioning that the research report presented here was guided by COREQ, which is a consolidated script for dissemination of qualitative studies ${ }^{(21)}$. The theoretical framework that supported analysis of the results obtained comes from the assumptions regarding TFs existing in the group context.

\section{Study setting}

This study was carried out at four Psychosocial Care Centers for Alcohol and Drugs (CAPSad - Centros de Atenção Psicossocial Álcool e Drogas), open and community health services, specialized in assisting alcohol and other drug addicts, which are based on treatment of patients in freedom, seeking their reintegration Social. All are located in a large municipality in center-western Brazil, with two CAPSad type II, one CAPSad type III and one CAPSiad (children and youth). 
The classification of these services varies according to the population size of the municipalities, being type II for those with more than 70 thousand inhabitants and type III when they have more than 150 thousand inhabitants and open 24 hours a day, seven days a week. CAPSiad aims at assisting children and adolescents who have intense mental suffering from alcohol and other drug use, recommended for municipalities with a quantity above 70 thousand inhabitants ${ }^{(22)}$.

\section{Data source}

The selection of respondents was carried out through nonprobabilistic sampling. Thirty health professionals, with a medium or higher education level, participated in this study, including managers. Inclusion criteria were considered to be over 18 years old, to have experience or to be developing work with groups and to be in professional practice during the period of data collection. Exclusion criteria were the removal of professionals due to vacation or leave from work.

\section{Data collection and organization}

Data were obtained through a professional profile questionnaire, TF assessment instrument and semi-structured interview script for a conversation round ${ }^{(23)}$. The latter contains 11 guiding questions to know professionals' perceptions about their practices with groups in the psychosocial care setting: 1) How are the professionals who coordinate the groups defined? 2) What criteria for creating these groups? 3) Is there planning for each group meeting? Or is there planning for general care? How is this process? 4) How is the user referred to the groups? How is the therapeutic recommendation designed to refer a user to the group? 5) Where do the groups take place? How is the structure of the places where they are held? 6) Do the coordinators use group techniques when conducting appointments? How are the techniques chosen? How is the group conducted? 7) Is there any type of assessment about the therapeutic effectiveness of groups for each participant? 8) Are there any criteria for discharge in group care? Or for the appointment of other groups/workshops? 9) Do you identify, in your group visits, factors that facilitate and factors that hinder the conduct of groups? 10) Do you feel the need to equip yourself with regard to group management? 11) Is there any theme that you would like to deepen in a possible permanent education process? We highlight the issue about the therapeutic effects of groups for this article, which focused on discussions about group effectiveness, according to professionals' perceptions.

The TFinstrument ${ }^{(23)}$ was built based on Yalom's and Leszcz's $s^{(3)}$ and Vinogradov's and Yalom's ${ }^{(24)}$ framework by a staff of researchers. 11 closed questions were elaborated, one for each TF, not referring to the technical name, but to the expression of the phenomenon in the group context, with a simpler and more objective language. There were four registry variables for each item, to identify the occurrence of TFs in practice with groups of professionals (never, rarely, frequently, and always). After elaboration, the instrument was sent via e-mail to researchers on the theme of groups and health literacy for assessment and validation in relation to form and content, receiving feedback from three group technology experts and one from health literacy.
After construction of data collection instruments, a pilot test was carried out in a CAPS with the staff of researchers, simulating all the chronological stages of the study, and the emerging data were analyzed strictly to verify the achievement of the proposed objectives for, later, enter the field of research itself.

Data collection took place between April and March 2019, in the respective services and on previously scheduled dates, coinciding with the regular meetings of the staffs, seeking to favor the largest number of participants in the research. At least two researchers participated at all times.

Conversation round $(\mathrm{CR})$ was chosen as the guiding strategy for data collection due to the fact that researchers approached group technology as a tool for transforming reality, through sharing experiences and building new knowledge collectively, group members play an active role in this process. It is a strategy that aims to stimulate reflection, the exchange of experiences of employees and the insertion of new information, for the re-signification of meanings about the theme addressed. It is important to create a safe environment for a dialogue between participants through listening, stimulating speech and using techniques to mobilize the group. It is a participatory methodology of punctual psychosocial intervention, used in several spaces to provide reflection on a theme. The maximum number of ideal participants is up to 30 people, to ensure that everyone can speak and be heard ${ }^{(25)}$.

$\mathrm{CR}$ is commonly divided into three moments: 1 . Preparation (with the initial welcoming of participants, awareness and encouragement to the interactive process of dialogue); 2 . Work (in which the theme is processed, favoring participants' explanation encouraging reflection); 3 . Assessment (time to find out what was learned and learned by the group) ${ }^{(25)}$.

Four CRs were carried out, in total, one in each service studied. In preparation stage, professionals were sensitized to the theme and participation in the research, with the study's objectives and the way data collection was going to be explained by the researchers. After signing the consent form, participants started to present themselves, and the material was delivered by the staff of researchers (paper, marker, brooch or string), so that they could make a badge with the name they would like to be called. Then, each one was asked to verbalize a quality that they believed to have, to create a welcoming and warm atmosphere for the next stage.

Subsequently, in the work stage, participants were instructed to complete the questionnaire with a professional profile, in order to obtain the characterization of the staffs working in the studied services, in addition to identifying which workers were involved in group activities. Then, the TF assessment instrument was applied to everyone who undertook group interventions at that time, with a view to verifying their perception of TFs in actions that were involved. Among the 25 professionals who claimed to coordinate groups currently inCAPS, two were unable to answer the instrument, as they had to be absent at this time of data collection due to service demands. In the sequence, the guiding questions were triggered, in order to better know their perceptions about the factors with possible therapeutic effects in the group care they undertake with CAPSad users. Finally, the meetingAssessment was carried out using the soliloquy technique ${ }^{(26)}$, which consisted of the vocalization of a word that reflected the way that professionals were leaving that moment. 
Each meeting lasted about two hours and were recorded in a digital voice recorder and transcribed for later analysis, with records also in a field diary, made by the research assistant trained for this purpose. This activity was coordinated by three facilitators, the researcher also responsible for postgraduate studies in group dynamics and staff management, a master teacher with training in consulting and group management and an academic research assistant in nursing. After analyzing the data, an educational process was offered based on the diagnosis of professionals' knowledge about group technology during data collection, using workshop as a strategy.

\section{Data analysis}

The content from data collection instruments (professional profile questionnaire and TF assessment instrument) and CRs and field diary were submitted to Bardin's content analysis(27), using the Atlas.ti software ${ }^{(28)}$, specific for qualitative data analysis. Material categorization was carried out in accordance with the steps of content analysis, consisting of three stages: pre-analysis (phase marked by organization: choice of documents to be analyzed, formulation of hypotheses and objectives and creation of elements that can subsidize the final interpretation, in order to carry out a systematization of initial ideas through text skimming); material exploration (consists of coding, decomposition or enumeration operations); treatment of results and interpretation (simple or more complex statistical operations, result charts, diagrams, figures and models that illustrate the information obtained in analysis) ${ }^{(27)}$.

\section{RESULTS}

\section{Participant characterization}

Most participants were female (27/30), aged between 28 and 64 years old. The training of professionals covered a diversity: psychology (10), social work (5), music therapy (3), arts (3), nursing technician (3), nursing (2), occupational therapy (2), physical education (1) and public management (1). Regarding specialization, 6 had mental health, 16 in other fields and 8 had no.

In CRs, we had participation of four professionals at CAPS 1, nine professionals at CAPS 2, eight professionals at CAPS 3 and eight professionals at CAPS 4, with a total of 29 participants, as a technician from one of the services was unable to participate at that time to provide assistance at CAPS welcoming.

\section{Occurrence of therapeutic factors in the groups}

TFs are an important tool for measuring effectiveness in groups. Table 1 shows the perception of 23 professionals about the functioning of the groups through the responses of an instrument on TFs, applied during CR performance. Data are presented in absolute frequency.

\section{Categorization}

To complement, validate and deepen the information collected by the TF instrument, some questions were asked in CRs, specific about therapeutic effectiveness of groups and according to the content analysis. The meanings and of participants' statements were grouped into categories and subcategories that reflect the practice with groups in CAPSad. The focus in this study focuses on the category Characteristics of group care, in which subcategory Perception of therapeutic effectiveness of groups emerged, bringing the perceptions of the multidisciplinary staffs on the therapeutic effects in group care in the scenario of mental health and psychosocial care.

\section{Perception of therapeutic effectiveness}

Regarding the perception of the therapeutic effectiveness of the groups, even without having systematic and formal knowledge, because, during the moments of reflection in CR, professionals did not refer to TFs as a mechanism for assessing group care according to Yalom's and Leszcz's theoretical framework ${ }^{(3)}$. There is a scarcity of records and difficulty of standardizing the way of assessing whether the group is working or not. Even so, when describing the phenomena that permeate their practices with groups in services, some of TFs emerged, such as altruism, instillation of hope, development of socialization techniques, group cohesion and imitative behavior, relating them to the process of assessing the group progression. Professionals reported situations that they consider to be therapeutic indicators observed during group care (Chart 1).

Chart 1 - Professionals' perception of intra-group therapeutic effectiveness at Psychosocial Care Centers for Alcohol and Drugs, Goiânia, Goiás, Brazil, 2019

\begin{tabular}{|l|l|l|}
\hline $\begin{array}{l}\text { Therapeutic } \\
\text { factor }\end{array}$ & $\begin{array}{l}\text { Therapeutic } \\
\text { indicators }\end{array}$ & Professionals' statements \\
\hline Altruism & $\begin{array}{l}\text { Mutual care } \\
\text { among } \\
\text { group } \\
\text { members }\end{array}$ & $\begin{array}{l}\text { We notice improvement, behavior } \\
\text { change, self-care, care for others, in } \\
\text { the sense of solidarity with the group, } \\
\text { with someone, the perception of what } \\
\text { the other person does, if that bothers } \\
\text { me, it touches me. If that drives you in } \\
\text { any way, it is a lot for what they say, for } \\
\text { the behavior and reports of decreased } \\
\text { use reduction, or even abstinence. (P2 } \\
\text { - CAPS 1) }\end{array}$ \\
\hline
\end{tabular}

To be continued 
Chart 1 (concluded)

\begin{tabular}{|c|c|c|}
\hline $\begin{array}{l}\text { Therapeutic } \\
\text { factor }\end{array}$ & $\begin{array}{l}\text { Therapeutic } \\
\text { indicators }\end{array}$ & Professionals' statements \\
\hline $\begin{array}{l}\text { Instillation of } \\
\text { hope }\end{array}$ & $\begin{array}{l}\text { User } \\
\text { progress/ } \\
\text { improvement } \\
\text { reports }\end{array}$ & $\begin{array}{l}\text { The issues they verbalize "Ah, at my house } \\
\text { things are better, because I am like this, } \\
\text { because I did this, because that happened". } \\
\text { (P1-CAPS 1) } \\
\text { The main assessment is their speech [...] } \\
\text { what they bring that changed their lives, } \\
\text { what has not improved, the way he arrived } \\
\text { and how he is today. (P7 - CAPS 2) } \\
\text { The statements about the acquisitions } \\
\text { that people had after participating in the } \\
\text { group for us are very important, I realize } \\
\text { this a lot in the family group. They bring up } \\
\text { these questions of how they were before } \\
\text { they came to the group and how they } \\
\text { behave now. (P25 - CAPS 4) }\end{array}$ \\
\hline $\begin{array}{l}\text { Development } \\
\text { of socialization } \\
\text { techniques }\end{array}$ & $\begin{array}{l}\text { Observation } \\
\text { of change in } \\
\text { behavior }\end{array}$ & $\begin{array}{l}\text { [...] I remembered, when you were there } \\
\text { talking, about moments like this, about } \\
\text { participants who arrived very well, } \\
\text { interacting little with the others, the } \\
\text { next day they arrived, stripped down, } \\
\text { lay down and felt part of that space, } \\
\text { belonging to that, introduced the group } \\
\text { to other people. I think these things were } \\
\text { showing. (P15 - CAPS 3) }\end{array}$ \\
\hline Cohesion & $\begin{array}{l}\text { User stay in } \\
\text { the group }\end{array}$ & $\begin{array}{l}\text { First is permanence, whether an individual } \\
\text { remains or not. (P1 - CAPS 1) } \\
\text { I think that, according to frequency, we will } \\
\text { assess. (P15 - CAPS 3) } \\
\text { In the family group, one thing that I think } \\
\text { also makes assessment possible is the } \\
\text { frequency. We have a number of people } \\
\text { who have been frequent for a long time, } \\
\text { and are committed to this group, they } \\
\text { feel good, they bring it to the group. (P25 } \\
\text { - CAPS 4) }\end{array}$ \\
\hline $\begin{array}{l}\text { Imitative } \\
\text { behavior }\end{array}$ & $\begin{array}{l}\text { Imitative } \\
\text { behavior } \\
\text { report }\end{array}$ & $\begin{array}{l}\text { In the family group, we see each other's } \\
\text { experiences, what happens, there is one } \\
\text { that is starting now and that at the time } \\
\text { of the report said "Look, I tried to do this } \\
\text { with my son, it is working". [...] so, in the } \\
\text { case of this teenager who was with his } \\
\text { mother, it is working. (P18 - CAPS 3) }\end{array}$ \\
\hline
\end{tabular}

Chart 2 - Professionals' perception of the therapeutic effectiveness of group activity at the end of group meetings and at extra moments of groups from Psychosocial Care Centers for Alcohol and Drugs, Goiânia, Goiás, Brazil, 2019

\begin{tabular}{|l|l|}
\hline $\begin{array}{l}\text { Indicative elements } \\
\text { of therapeutic } \\
\text { effectiveness }\end{array}$ & Professionals' statements \\
\hline $\begin{array}{l}\text { Recommendation of } \\
\text { CAPS by users }\end{array}$ & $\begin{array}{l}\text { Other results that I see, like this, I think a little } \\
\text { recommendation that you are having here } \\
\text { at CAPS. They say: "I have to go to CAPS". So, } \\
\text { something is happening there. (P3 - CAPS 1) }\end{array}$ \\
\hline $\begin{array}{l}\text { Discussion among } \\
\text { post-group } \\
\text { coordinators }\end{array}$ & $\begin{array}{l}\text { Usually, when the group has more than one } \\
\text { coordinator, always at the end of the group the } \\
\text { coordinators talk, how was the dynamics, how } \\
\text { was adolescents' acceptance. (P19 - CAPS 3) }\end{array}$ \\
\hline $\begin{array}{l}\text { Reaching the group } \\
\text { goal }\end{array}$ & $\begin{array}{l}\text { Ithink this moment of assessment is a process of } \\
\text { change, the group has the objective that you hoped to } \\
\text { achieve with it. You will reassess this during the group, } \\
\text { realize that you are going towards that objective, this } \\
\text { verbally, I think it is also an recommendation that } \\
\text { you are reaching the objectives, it is what I have used } \\
\text { within the groups. (P17 - CAPS 3) }\end{array}$ \\
\hline
\end{tabular}

To be continued

\begin{tabular}{|c|c|}
\hline $\begin{array}{l}\text { Indicative elements } \\
\text { of therapeutic } \\
\text { effectiveness }\end{array}$ & Professionals' statements \\
\hline $\begin{array}{l}\text { Assessment of the } \\
\text { group process from } \\
\text { users' perspectives }\end{array}$ & $\begin{array}{l}\text { At least in the group I was in, we always have the } \\
\text { habit of asking for an assessment at the end of } \\
\text { each meeting, I think this is a way of assessing. } \\
\text { (P6 - CAPS 2) } \\
\text { I think that we have also used feedbacks even } \\
\text { at the end of the group or during. A super basic } \\
\text { form of assessment or recording, like drawings, } \\
\text { like musical composition, we used this type of } \\
\text { assessment here". (P17 - CAPS 3) } \\
\text { I think one thing that we can say that it is a } \\
\text { possibility of assessment is to always be talking in } \\
\text { the group to understand what they are thinking, } \\
\text { what the group is perceiving, if they are feeling } \\
\text { well, if the way we are approaching it's cool. (P25 } \\
\text { - CAPS 4) }\end{array}$ \\
\hline
\end{tabular}

Professionals also pointed out elements that could measure the therapeutic effectiveness of group activity at the end of group meetings and at times outside groups, such as the discussion among the coordinators after the group, assessment of achievement of objectives or recommendation of CAPS by users and request for feedback from the group members before the end of service (Chart 2).

\section{DISCUSSION}

TF identification is an assignment of the group coordinator with the aim of understanding the transformations of the group members ${ }^{(3)}$. To identify these factors, the coordinator is able to reflect on the group process and understand its movement ${ }^{(29)}$. It is important to understand that TFs are strictly related to the coordination of the facilitator, group members and the chosen techniques ${ }^{(30)}$.

In a service, there can be a diversity of groups and manifest different TF depending on the forces impact the therapeutic mechanisms and the group, such as type of group, stage of therapy and individual differences between patients ${ }^{(24)}$. These factors are tools that make it possible to understand the functioning of the creative group through maintenance and development, which provides and strengthens conditions favorable to chang $\mathrm{e}^{(13)}$.

This study showed the presence of several TFs in the groups performed in CAPSad according to health professionals. The universality, information sharing and group cohesion were the TF identified in all groups performed by them. Some others, such as imitative behavior, instillation of hope, altruism, catharsis, cohesion and existential factors were observed in most group visits. On the other hand, the corrective reissue of the primary family group, existential factors and the development of socialization techniques were never identified by professionals in the TF instrument.

TF presence was also signaled by other studies: in a group aimed at assisting people living and living with HIV/AIDS, it was possible to identify numerous of these factors, through the experiences of their participants, such as information sharing, corrective recap of the primary family group, development of socialization techniques, interpersonal learning, imitative behavior, group cohesion and altruism ${ }^{(31)}$; with a group of people with diabetes, the following were verified: offering information, 
cohesion, universality, development of socialization techniques, interpersonal learning, instillation of hope, altruism and imitative behavior ${ }^{(32)}$.

In the field of mental health, the literature points to research that portrays TF existence in group interventions, as described by Yalom and Leszcz ${ }^{(3)}$ : in a group of child dynamics offered by a psychological clinic of a Brazilian state university aimed at children up to 11 years old, during their daily practice, TF were identified, such as information sharing, imitative behavior, catharsis, among others ${ }^{(33)}$; with a group of voice hearers in a CAPS, over 62 sessions, universality, interpersonal learning, altruism and information sharing were identified through the group members' experiences ${ }^{(34)}$. Such results show TF presence in different groups and in different fields of health, although, many times, the group coordinators themselves are not clear about the potential of the group interventions they conduct and, as a rule, are unaware of the theoretical constructs referring to this topic.

This study, in turn, identified different frequencies of therapeutic factors in care at CAPS, ranging from never, rarely, frequently and always present, in the groups performed by health professionals. This fact can be justified by the fact that it is not possible to guarantee that all TFs manifest at the same time in the group's life, as some are more present in some stages of the group process ${ }^{(29)}$.

During CRs with professionals, the groups' therapeutic effectiveness was attributed to factors such as altruism, instillation of hope, development of socialization techniques and group cohesion and imitative behavior; although mentioned without the proper theoretical understanding of each of them and admittedly not used as parameters of systematic assessment of the group's progression. It is important to know that TFs are interdependent and complementary at a given time to manifest themselves in the group ${ }^{(3)}$.

Altruism was made explicit by the mutual care between members and the group. This TF is typical of group therapy, being related to the experience of a group member being useful to others through the socialization of similar problems and offering care and support, suggestions, insights and relaxation ${ }^{(3)}$.

The instillation of hope was revealed through reports of improvement of group members or testimony of progress obtained by them, which arouse high hopes for those who receive this message, enhancing users' belief in the group treatment model $^{(3)}$. Moreover, in the group context, each member is at a level of confrontation, and contact with other people who have made progress during group treatment could give hope to others who still feel fragile ${ }^{(35)}$.

TFs related to the development of socialization techniques could also be evidenced in the testimony of one of the group coordinators, who mentioned the change in introspective behavior of a member of the group to a more sociable attitude. It revealed a social learning and development of basic social skills to relate directly, honestly and intimately with other people in the group ${ }^{(3)}$.

Group cohesion, in turn, provides an in-depth relationship, in which group members are willing to reveal themselves, take risks and face conflicts, as well as the process of interpersonal acceptance and understanding, in addition to users' commitment to the group ${ }^{(3,36)}$. It is a very important element, as it is a prerequisite for other TFs to be able to operate in the group, being related to the stability of its members, because the less cohesive participants are, the greater the probability of rupture with the group. Moreover, low-cohesive groups have a higher turnover of people, which can harm regular users and, consequently, group effectiveness $^{(3)}$.

In this study, this TF was identified by frequency and involvement of group participants among themselves. Cohesion, therefore, is related to connection that group members have with each other and with the group as a whole. Groups that present exacerbated cohesion, feelings such as affection, comfort, belonging, personal appreciation and acceptance emerge in the group context with greater fluidity, making the members of the group feel more comfortable to expose their emotions ${ }^{(35)}$.

Another TF, evidenced in one of the statements, was that of imitative behavior, which can manifest itself through the imitation of a new behavior mirrored both in the group coordinator and in the other members, concretizing an experimentation of new actions ${ }^{(3)}$. In addition to allTFs present in the group dynamics, important elements were reported by participants, such as the assessment of the group and therapeutic process. At the end of the meetings, the coordinators ask participants for feedback. Feedback allows assessingservice effectiveness, as well as the group process from users' perspectives, and in extra group moments, such as the recommendation of CAPS by users themselves, the discussion between the post-group coordinators and the achievement of the objectives set for the respective interventions.

The recommendation and/or disclosure of service by users signals a confirmation of benefits that assistance of CAPSad provides to them. This connotation is in line with some of the principles of humanized health care, in terms of user satisfaction. They express their desire to remain under the care of CAPSad as a member of the groups, including wanting it to benefit others who need health care in alcohol and other drugs. Humanization of health care favors the transformation at the level of management and the activities of the health staff, which reaches health users comprehensively, from welcoming, professional ethical attitude, understanding of the subjectivity of the other and understanding of the subject singular ${ }^{(37)}$.

Thus, the assessment of the group coordinators after the intervention is necessary to measure the group process, in addition to the relative weightings of each participant element in the visualization of the respective unique therapeutic projects. This assessment is possible when the coordinators work from the perspective of co-therapy, which makes complementary action possible from the planning of the group to the assessment of group phenomena. ${ }^{(3,38)}$. This practice strengthens teamwork by sharing perceptions about the group process and consequent analysis of the group's progression. From the shared reflections, it is possible to undertake the necessary adjustments between the group's objectives and the coordinator, and the objectives established by the group itself must be prioritized ${ }^{(39)}$.

The frequency of users in the groups is another factor to be considered, since some users are linked to CAPS and groups in order to comply with socio-educational measures, remaining in the institution only for the period determined by the court. Despite this possibility, it is necessary to consider the therapeutic objectives of following the interventions that users participated in. 
Professionals reported feedback as a way of assessing group effectiveness and process from users' perspectivesconsidering what is said about their development and the role of the coordinator. In order to achieve an objective, behaviors that are guided by feedback are necessary, and the return to the sender is fundamental in the context of interpersonal relationships. That said, it is essential that members and not just the group coordinator improve the ability to give and receive individual feedback and also to the group itself ${ }^{(40)}$.

Finally, the researcher, who is also a group coordinator, when dealing with phenomena related to intra and interpersonal relationships in the group context, needs to recognize that his attitude is decisive on the repercussions on the group dynamics. During the process, he can play different roles in face of events within the group ${ }^{(38,41)}$. However, regardless the position taken by him, recognizing and assessing TFs intrinsic to the group is essential, as it can provide elements in mechanism identification that contribute to the transformation of those involved in this process ${ }^{(35)}$.

\section{Study limitations}

During the investigative process, there were limitations regarding mental health units functioning, which, at times, prevented more professionals from participating in data collection moments due to the great demand for services. Furthermore, as it is part of qualitative research, the results found should not be generalized, although they make it possible to highlight the context of meanings expressed in practice with groups of mental health professionals and the consequent expansion of horizons in assisting this specific public.

The analysis carried out did not allow reflecting on the relationship between the types of groups and TFs, the professional categories and models of coordination. These limits contribute for new investigations to be outlined in service, or for new analyzes on the same corpus to be conducted in the future, contributing to the field.

\section{Contributions to health and nursing}

The reflections presented in this article showed the potential of TFs in group work, enabling the assessment of the group process at different times. It allowed understanding of the group's functioning, providing an important tool for health professionals in their nursing and health care practices, in general, from the perspective of comprehensive health care. It is fully possible to use group technology in other care contexts in the diversity of health services, community spaces, education, people management and at different levels of care, or as a strategy for prevention and health promotion.

\section{FINAL CONSIDERATIONS}

It was possible to understand that TFs were perceived by professionals in their group practices, which reveals the importance of these care strategies within psychosocial care, even though still a large part of them did not have theoretical knowledge on the subject. The fact that they do not systematically record reports and or memories about group interventions makes them fail to perceive important elements in assessment of therapeutic effectiveness of groups.

What is not registered becomes invisible in users' therapeutic process. It gives a connotation of less value to the intervention itself, and, insofar as it is not valued by professionals, it implies a feeling of frustration, for performing an apparently meaningless action. Scarcity of records has an impact beyond the meaning of absence of data recorded in the medical records, with implications that weaken since individual service user evolution, the group actions carried out until the generation of data of what actually occurs in the services dynamics.

Another aggravating factor is related to the information systems recommended by SUS, which are depleted of elements necessary for the adoption of evaluative measures of interventions mediated by group technology in specialized services network. This is a worrying reality, especially when considering the recommendation of public policies for the field of mental health that CAPS care should be essentially offered in group contexts, subject to the use of numerous therapeutic resources, undeniably potent and that could be better exploited and used for the social reintegration of people who are served in specialized services.

It is worth mentioning that the interactive process between researchers and CAPSad professionals who led groups was the differential so that they could become aware that the practice they undertake is rich in therapeutic options, which can give existential meaning to those involved in the process.

The need to conduct further research on the theme is pointed out, both in community mental health services and in other health care scenarios at their different levels of complexity, where group practices are implemented, incorporating, in addition to group coordinators, users participating in interventions.

\section{ACKNOWLEDGMENT}

We thank the Coordenação de Aperfeiçoamento de Pessoal de Nível Superior (CAPES) for their financial support and RECUID - REFLETIR PARA CUIDAR - Grupo Interdisciplinar de Pesquisa e Intervenção em Saúde Mental at the Faculdade de Enfermagem (FEN) of the Universidade Federal de Goiás (UFG).

\section{REFERENCES}

1. Carvalho Jr ACN, Amparo DM, Nogueira RN. O grupo de escuta como um dispositivo clínico em um centro de atenção psicossocial (CAPS II). Psicol Clín. 2019;31(1):123-43. doi: 10.33208/PC1980-5438v0031n01A06

2. Pinho ES, Nunes FC, Vale RRM, Sousa JM, Silva NS. Grupo operativo como estratégia do processo de ensino aprendizagem. GEPESVIDA [Internet]. 2019 [cited 2020 Jun 4];5(11):14-29. Available from: http://www.icepsc.com.br/ojs/index.php/gepesvida/article/view/345/175

3. Yalom ID, Leszcz M. Psicoterapia de grupo: teoria e prática. 5th ed. Porto Alegre, RS: Artmed; 2006.528 p. 
4. Nogueira ALG, Munari DB, Santos LF, Oliveira LMAC, Fortuna CM. Therapeutic factors in a group of health promotion for the elderly. Rev EsC Enferm USP. 2013;47(6):1352-8. doi: 10.1590/S0080-623420130000600015

5. Heldt E, Behenck AS, Wesner AC. Psicoterapias em grupo. In: Cordioli AV, GrevetEH,organizadores. Psicoterapias: abordagens atuais. 4: Artmed; 2019. 87-101 p.

6. Brunozi NA, Souza SS, Sampaio CR, Maier SRO, Silva LCVG, Sudré GA. Therapeuticgroup in mental health: intervention in the family health strategy. Rev Gaúcha Enferm. 2019;40(e20190008):1-09. doi: 10.1590/1983-1447.2019.20190008

7. Campêlo SR, Barbosa MA. Grupo terapêutico e qualidade de vida no CAPS AD Casa: relato de experiência. In: Motta KAMB, Munari DB, organizadores. As trilhas do trabalho de grupos: teorias e aplicabilidade. Curitiba: CRV; 2016. 77-85 p.

8. Nunes FC, Caixeta CC, Pinho ES, Souza ACS, Barbosa MA. Group technology in psychosocial care: an dialogue between action-research and permanent health education. Texto Contexto Enferm. 2019;28(e20180161):1-13. doi: 10.1590/1980-265x-tce-2018-0161

9. Besseling EM, Schellekens MPJ, Spinhoven P, Compen FR, Speckens AEM, van der Lee ML. Therapeutic alliance-not therapist competence or group cohesion: contributes to reduction of psychological distress in group-based mindfulness-based cognitive therapy for cancer patients. Clin Psychol Psychother. 2019;26:309-318. doi: 10.1002/cpp.2352

10. Guanaes $C$, Japur M. Grupo de apoio com pacientes psiquiátricos ambulatoriais em contexto institucional: análise do manejo terapêutico. Psicol Reflex Crít. 2001;14(1):191-9. doi: 10.1590/S0102-79722001000100016

11. Andrade JMM, Farinha MG, Esperidião E. Mental Health Nursing: waiting room intervention in integral health care. Rev Bras Enferm. 2020;73(Suppl 1):e20180886. doi: 10.1590/0034-7167-2018-0886

12. Guanaes $C$, Japur M. Fatores terapêuticos em um grupo de apoio para pacientes psiquiátricos ambulatoriais. Braz J Psychiatry. 2001;23(3):134-40. doi: 10.1590/S1516-44462001000300005

13. Santos MA, Scorsolini-Comin F, Gazignato ECS. Aconselhamento em saúde: fatores terapêuticos em grupo de apoio psicológico para transtornos alimentares. Estud Psicol. 2014;31(3):393-403. doi: 10.1590/0103-166×2014000300008

14. Oliveira LMAC, Medeiros M, Brasil VV, Oliveira PMC, Munari DB. Use of therapeutic factors for the evaluation of results in support groups. Acta Paul Enferm. 2008;21(3):432-8. doi: 10.1590/S0103-21002008000300008

15. Ministério da Saúde (BR). Conselho Nacional de Saúde. Comissão Nacional de Ética em Pesquisa. Resolução no 466/2012. Aprova diretrizes e normas regulamentadoras de pesquisas envolvendo seres humanos [Internet]. Brasília: Ministério da Saúde; 2012[cited 2020 Apr 16]. Available from: https://bvsms.saude.gov.br/bvs/saudelegis/cns/2013/res0466_12_12_2012.html

16. Rocha ML, Aguiar KF. Prácticas universitarias y formación socio-política. Acheronta [Internet]. 2000 [cited 2020 Apr 16];(11). Availablefrom: http://www.acheronta.org/acheronta11/socio-politica.htm

17. Aguiar KF, Rocha ML. Pesquisa-intervenção e a produção de novas análises. Psicol Ciên Prof. 2003;23(4):64-73. doi: 10.1590/ S1414-98932003000400010

18. Rocha ML. Psicologia e as práticas institucionais: a pesquisa-intervenção em movimento. Psicol (Porto Alegre) [Internet]. 2006 [cited 2020 Jun 4];37(2):169-74. Available from:http://revistaseletronicas.pucrs.br/ojs/index.php/revistapsico/article/viewFile/1431/1124

19. Rocha ML. Formação e prática docente: implicações com a pesquisa-intervenção. In: Maciel IM, organizador. Psicologia e educação: novos caminhos para a formação. Rio de Janeiro: Ciência Moderna Ltda; 2010. 184-8 p.

20. Polit DF, Beck CT. Fundamentos de pesquisa em enfermagem: avaliação de evidências para a prática da enfermagem. 9th ed. Porto Alegre, RS: Artmed; 2019.456 p.

21. Tong A, Sainsbury P, Craig J. Consolidated criteria for reporting qualitative research (COREQ): a 32-item checklist for interviews andfocusgroups. Int J Qual Health Care. 2007;19(6):349-57. doi: 10.1093/intqhc/mzm042

22. Ministério da Saúde (BR). Secretaria de Atenção à Saúde. Departamento de Atenção Especializada e Temática. Centros de Atenção Psicossocial e Unidades de Acolhimento como lugares da atenção psicossocial nos territórios: orientações para elaboração de projetos de construção, reforma e ampliação de CAPS e de UA [Internet]. Brasília: Ministério da Saúde; 2015[cited 2020 Apr 16]. Available from: http:// bvsms.saude.gov.br/bvs/publicacoes/centros_atencao_psicossocial_unidades_acolhimento.pdf

23. Sousa JM. Intervenções grupais em Centros de Atenção Psicossocial AD 2020[Dissertação].. Goiânia. Universidade Federal de Goiás; 2020.

24. Vinogradov S, Yalom ID. Manual de psicoterapia de grupo. Porto Alegre: Artes Médicas; 1992. 215 p.

25. Afonso MLM, Abade FL. Vamos entrar na roda? a metodologia das rodas de conversa. In: Afonso MLM, Abade FL. Para reinventar as rodas [Internet]. Belo Horizonte: Rede de Cidadania Mateus Afonso Medeiros (RECIMAM); 2008. pp. 19-39

26. Gonçalves CS, Wolff JR, Almeida WC. Lições de psicodrama: introdução ao pensamento de J. L. Moreno. 11 ed. São Paulo: Ágora; 1988.112 p.

27. Bardin L. Análise de conteúdo. 3 reimp. tradutor, Reto LA, Pinheiro A, editores. Lisboa, Portugal: Ediçoes 70; 2018.181 p.

28. Walter SA, Bach TM. Adeus papel, marca-textos, tesoura e cola: inovando o processo de análise de conteúdo por meio do ATLAS.ti. Adm Ensino e Pesqui. 2015;16(2):275-306. doi: 10.13058/raep.2015.v16n2.236

29. Munari DB, Furegato ARF. Compreendendo os grupos e sua aplicação na enfermagem. In: Munari DB, Furegato ARF, organizadores. Enfermagem e grupos. 2nd ed. Goiânia: AB; 2003. 13-7 p.

30. Valentin F, Conceição MIG. Fatores terapêuticos nos grupos de musicoterapia: a catarse como experiência coletiva. In: Motta KAMB, Munari 
DB, organizadores. As trilhas do trabalho de grupos: teorias e aplicabilidade. Curitiba: CRV; 2016. 125-40 p.

31. Afonso DH, Silveira LMC, Deveza M, Marques EL, Bártholo TP, Puig DSN. Fatos e marcas: das memórias e conquistas do Grupo Com Vida. Med. HUPE-UERJ. 2016;15(3):261-70. doi: 10.12957/rhupe.2016.29471

32. Oliveira FN, Munari DB, Bachion MM, Santos WS, Santos QR. Therapeutic factors in a group of people with diabetes. Rev Esc Enferm USP. 2009;43(3):558-65. doi: 10.1590/S0080-62342009000300009

33. Ortolan MLM, Lima AL, Maireno DP, Sei MB. Grupos de dinâmica infantil e os efeitos terapêuticos do brincar. Rev SPAGESP [Internet]. 2018[cited 2020 Apr 16];19(2):23-33. Available from: http://pepsic.bvsalud.org/pdf/rspagesp/v19n2/v19n2a03.pdf

34. Fernandes HCD, Zanello V. The group of voice hearers: mental healthcare device. Psicol Estud. 2018;23(e39076):1-12. doi: 10.4025/ psicolestud.v23.e39076

35. Oliveira LMAC, Santos LFC. Avaliação do uso do grupo como estratégia para acolhimento de familiares. In: Oliveira LMAC, Santos LFC, organizadores. Trabalhando com grupos na assistência a familiares em UTI. Curitiba: Appris; 2015. 36-42 p.

36. Motta KAMB, Fabiano FA. Contribuições para o coordenador de grupos abertos. In: Motta KAMB, Munari DB, organizadores. As trilhas do trabalho de grupos: teorias e aplicabilidade. Curitiba: CRV; 2016. 47-56 p.

37. Botelho JV, Lima MV. Percepção das emoções dos usuários do CAPS II: um relato de experiência. Fractal Rev Psicol. 2015;27(2):160-4. doi: 10.1590/1984-0292/929

38. Nunes FC, Farinha MG, Valentin F, Barbosa MA, Rua MS. Group interventions and action research in health application possibilities. Millenium: J Educ Technol Heal. 2020;2(11):65-71. doi: 10.29352/mill0211.07.00273

39. Leal ML, Motta KAMB, Munari DB, Freitas ACSRV, Martins VF. Análise do campo de forças de Kurt Lewin: uma estratégia para as transformações no funcionamento grupal. In: Motta KAMB, Munari DB, organizadores. As trilhas do trabalho de grupos: teoria e aplicabilidade. Curitiba: CRV; 2016. 23-46 p.

40. Moscovici F. Desenvolvimento interpessoal: treinamento em grupo. 17th ed. Rio de Janeiro: José Olympio; 2008. 276 p.

41. Dávila SL. Relato da experiência em grupo - lidando com a criação de vínculos no grupo. Rev IGT na Rede [Internet]. 2015 [cited 2020 Apr 16];12(22):240-57. Available from:http://www.igt.psc.br/ojs 